\title{
Thermal remote sensing of ice-debris landforms using ASTER: an example from the Chilean Andes
}

\author{
A. Brenning ${ }^{1}$, M. A. Peña ${ }^{2}$, S. Long ${ }^{1}$, and A. Soliman ${ }^{1}$ \\ ${ }^{1}$ Department of Geography and Environmental Management, University of Waterloo, 200 University Avenue West, \\ Waterloo, Ontario, N2L 3G1, Canada \\ ${ }^{2}$ Centro de Estudio de Recursos Naturales Oterra, Universidad Mayor, Camino La Pirámide 5750, Huechuraba, \\ Santiago, Chile
}

Correspondence to: A. Brenning (brenning@uwaterloo.ca)

Received: 27 September 2011 - Published in The Cryosphere Discuss.: 24 October 2011

Revised: 17 February 2012 - Accepted: 26 February 2012 - Published: 30 March 2012

\begin{abstract}
Remote sensors face challenges in characterizing mountain permafrost and ground thermal conditions or mapping rock glaciers and debris-covered glaciers. We explore the potential of thermal imaging and in particular thermal inertia mapping in mountain cryospheric research, focusing on the relationships between ground surface temperatures and the presence of ice-debris landforms on one side and land surface temperature (LST) and apparent thermal inertia (ATI) on the other. In our case study we utilize ASTER daytime and nighttime imagery and in-situ measurements of near-surface ground temperature (NSGT) in the Mediterranean Andes during a snow-free and dry observation period in late summer. Spatial patterns of LST and NSGT were mostly consistent with each other both at daytime and at nighttime. Daytime LST over ice-debris landforms was decreased and ATI consequently increased compared to other debris surfaces under otherwise equal conditions, but NSGT showed contradictory results, which underlines the complexity and possible scale dependence of ATI in heterogeneous substrates with the presence of a thermal mismatch and a heat sink at depth. While our results demonstrate the utility of thermal imaging and ATI mapping in a mountain cryospheric context, further research is needed for a better interpretation of ATI patterns in complex thermophysical conditions.
\end{abstract}

\section{Introduction}

Rock glaciers and debris-covered glaciers are distinct types of ice-debris landforms and elements of the mountain cryosphere in which the high ice contents are not visible at the surface, creating challenges to remotely-sensed mapping of these features (Janke, 2001; Paul et al., 2004; Bolch et al., 2008; Kargel et al., 2005; Brenning, 2009; Shukla et al., 2010). Similarly, remote sensors have been of limited use in the characterization of permafrost and ground thermal conditions in mountain areas. However, thermal remote sensing provides a set of variables that are useful for characterizing thermal and thermophysical surface characteristics of the natural and built environment (Watson, 1975; Chen et al., 2008; Peña, 2009). Its potential are yet to be fully exploited in geomorphological and cryospheric research, and applications in mountain environments are still relatively rare (Van De Kerchove et al., 2009; Bertoldi et al., 2010), especially in the case of thermal inertia mapping (Piatek et al., 2007; Hardgrove et al., 2010).

We therefore explore the utility of remotely-sensed land surface temperature (LST) and derived apparent thermal inertia (ATI) for thermally characterizing and discriminating periglacial mountain environments, particularly rock glaciers and debris-covered glaciers. We demonstrate this approach utilizing ASTER daytime and nighttime data in a study area in the Andes of Central Chile, where in-situ near-surface ground temperature (NSGT) measurements are available for comparison with remotely-sensed LST (Bodin et al., 2010a; Apaloo et al., 2012).

This paper starts by providing thermophysical and cryological background information in Sect. 2. Section 3 presents the remote sensing methods, in-situ measurements and the statistical study design and analysis methods used in this study, and provides an introduction to the study area and relevant meteorological conditions. The results of statistical 
data analyses relating LST, ATI and NSGT observations to site characteristics are presented in Sect. 4, focusing in particular on differences between ice-debris landforms and other debris surfaces. These empirical findings are discussed in Sect. 5 in the context of heat transfer processes between the atmosphere, the surface debris layer, and ground ice.

\section{Background}

\subsection{Remote sensing of LST}

Satellite-based thermal infrared (TIR) data can be used to estimate LST over large and inaccessible areas. TIR is the optical region of the spectrum that comprises the wavelengths of emitted radiation or heat, which ranges from 3 to $14 \mu \mathrm{m}$ (mid-wave infrared 3-8 $\mu \mathrm{m}$ and longwave infrared 8-14 $\mu \mathrm{m}$ ). Earth surface features emit radiation as a function of their internal temperature (i.e. kinetic temperature) and their ability to emit radiation (i.e. emissivity). Emitted radiation is an external manifestation of the feature's energy state and it can be converted into radiant temperature of Earth surface features or LST (Lillesand et al., 2004).

LST is the external temperature of the Earth surface features (Weng and Quattrochi, 2006), and is one of the key parameters combining the results of all surface-atmosphere interactions and energy fluxes between the atmosphere and the ground. It is strongly dependent on the thermal properties of the material (Wan, 1997). LST is closely related to the atmospheric temperature of the layer immediately above the surface (Nichol, 1996; Hafner and Kidder, 1999; Weng and Quattrochi, 2006), although there are other influences as well (Hartz et al., 2006; Peña, 2009).

A critical thermal property of the material that controls the temporal behaviour of LST is thermal inertia or the response of a material to temperature changes. Earth surface features with high thermal inertia respond slowly to the solar pulse and as a consequence they tend to present a more uniform LST throughout the day and night than features with low thermal inertia (Watson, 1975; Lillesand et al., 2004). The utility of satellite-based TIR data for differentiating the LST of two land cover types can be limited because image acquisition time does not necessarily capture the moment when these land cover types exhibit their maximum thermal difference. In these cases, the retrieval of thermal inertia is often a more useful approach because it differentiates both land cover types from the perspective of the temporal behaviour in LST. From satellite-based daytime and nighttime TIR data it is possible to retrieve thermal inertia estimates, as outlined in the following section.

\subsection{Surface energy balance and thermal inertia}

The surface energy balance at the air-debris interface and its dependence on surface, air and debris temperatures, $T_{\mathrm{s}}, T_{\mathrm{a}}$ and $T_{\mathrm{d}}$ respectively, is given by (Reid et al., 2010)

$S+L \downarrow+L \uparrow\left(T_{\mathrm{s}}\right)+H\left(T_{\mathrm{s}}, T_{\mathrm{a}}, u\right)+L E\left(T_{\mathrm{s}}\right)+G\left(T_{\mathrm{s}}, T_{\mathrm{d}}\right)+P\left(T_{\mathrm{s}}\right)=0$

where $S$ is the total shortwave net radiation, $L \downarrow$ is incoming long wave radiation, $L \uparrow$ is outgoing long wave radiation, $H$ is sensible heat flux, $L E$ is latent heat flux, $G$ is ground flux, $u$ is wind speed, and $P$ is precipitation flux. Given the dry conditions at the surface, the terms $L E$ and $P$ can be omitted. The existence of a hidden frozen layer below the debris will add a heat sink that will influence the energy balance Eq. (1) by lowering the ground flux, which by consequence will lower the outgoing long wave flux given the stability of other flux and radiation terms. Solving the heat conduction equation with LST as an upper boundary condition shows that the thermal response of a homogeneous ground is controlled by a lumped thermal property called thermal inertia, TI, which is given by

$\mathrm{TI}=\sqrt{\rho c k}$

where $\rho$ is the bulk density, $c$ is the specific heat capacity and $k$ is the thermal conductivity.

Thermal inertia as a single thermal material property determines the surface temperature amplitude of a periodically heated half-space. This relationship can be used to estimate thermal inertia from daytime and nighttime LST, which is referred to as apparent thermal inertia (ATI). It is potentially useful for discriminating a wide variety of geological and geomorphological surface characteristics (Watson, 1975; Hardgrove et al., 2010). Thermal inertia is closely related to physical substrate properties as it correlates positively with density, moisture content, silica content, and negatively with the iron content (e.g. desert varnish) of a substrate's surface (Watson, 1975).

Different formulas for calculating ATI have been proposed in order to account for different measurement times and surface properties such as albedo (Li et al., 2004; Verhoef, 2004; Chen et al., 2008). In this study, we choose a representation that is based on the daily LST amplitude and accounts for spatially varying albedo and solar radiation. We therefore represent ATI by

$\mathrm{ATI}=\frac{\left((1-\gamma) S_{0}\right)}{\Delta T}$

where $\gamma$ is surface albedo, determined from the wavelengths of reflected radiation of the spectrum, $S_{0}$ is incoming solar radiation and $\Delta T$ is the maximum daily temperature difference. In our study the solar correction factor accounts for topographic radiation differences whereas previous studies modeled latitudinal variation of solar radiation (Nasipuri et al., 2006; Van doninck et al., 2011).

The relation between ATI and thermal inertia takes a linear form with scaling and offset factors, and the validity of ATI is limited to the case where linear coefficients are constant across the studied area (Price, 1985). There is a high potential in using such simple formulation in dry climates where 
latent heat flux is insignificant and the sensible heat flux is spatially invariant during the summer time.

\subsection{Ice-debris landforms and coarse blocky substrates}

Rock glaciers and debris-covered glaciers are different types of ice-debris landforms in high mountain areas that exhibit different internal thermal properties and interact differently with the atmosphere (Haeberli et al., 2006; Bodin et al., 2010a; Berthling, 2011). Debris-covered glaciers are typically part of the ablation area of glaciers in dry, continental mountain areas with high talus production. They present a supragracial debris layer typically up to $1-1.5 \mathrm{~m}$ thick and often exhibit melt-out depressions as the expression of vertical and lateral ice melt (Bodin et al., 2010a). Rock glaciers are considered to be the geomorphological expression of creeping ice-debris bodies under permafrost conditions (Haeberli et al., 2006). Their ice-rich inner part is protected relatively well against external temperature fluctuations by a seasonally thawing debris layer, the active layer, which is typically $3-5 \mathrm{~m}$ thick. However, this is not a static system as the active layer thickness is likely to increase over time as a consequence of climatic warming and the creep towards lower elevations (Haeberli, 2001; Trombotto and Borzotta, 2009). For convenience, we refer to debris-covered glaciers and rock glaciers jointly as "ice-debris landforms" (Berthling, 2011).

TIR imaging and especially thermal inertia mapping of ice-debris landforms is still a relatively novel approach that may provide insights into surface energy fluxes of these cryospheric features with variable debris cover thicknesses. ASTER-derived daytime LST on debris-covered glacier has been found to be several degrees lower than in adjacent areas not underlain by massive ice (Taschner and Ranzi, 2002), and it may serve as a proxy for debris cover thickness, at least for thin debris covers $<0.6 \mathrm{~m}$ (Mihalcea et al., 2008). It further has been suggested that ATI differs between the surfaces of ice-debris landforms and surrounding areas (Piatek et al., 2007; Piatek, 2009). A quantitative assessment of this conjecture is presented in this study. Bare, dry soil and cloudless skies are required to apply this approach (Watson, 1975), and these conditions are perfectly met in the summer-dry Andes during the snow-free period.

\section{Methods and data}

Our research approach is based on remotely-sensed and insitu data of ground thermal conditions and the use of statistical models for data analysis. Knowledge of the meteorological conditions at and before the image acquisition date and their climatic context is further required to understand atmospheric controls on the thermal state of the ground surface. This section starts with a general overview of relevant climatic and geomorphic conditions in the study area (Sect. 3.1), and continues by reporting on image acquisition
(Sect. 3.2) and procedures used for processing remote sensing data (Sect. 3.3). Meteorological conditions during image acquisition (Sect. 3.4) and in-situ measurements are presented next (Sect. 3.5). Finally, the statistical study design and data analysis methods are introduced (Sect. 3.6).

\subsection{Study area}

The study area is located in the western Main Cordillera of central Chile at the latitude of Santiago and comprises the Laguna Negra and Casa de Piedra catchments as well as adjacent areas above $3000 \mathrm{~m}$ a.s.l. (Fig. 1). Rock glaciers and (debris-covered) glaciers are widely distributed in this area (Brenning, 2005a, b; Bodin et al., 2010a; see also Sect. 3.5). The long dry summer season with infrequent cloud cover and the resulting dry soils provide ideal conditions for thermal imaging and thermal inertia mapping (Watson, 1975).

This study focuses on the area between 3000 and $3900 \mathrm{~m}$ a.s.l. The $0^{\circ} \mathrm{C}$ isotherm altitude (ZIA) of mean annual air temperature (MAAT) is located at $\sim 3600 \mathrm{~m}$ a.s.l., and the ZIA rises seasonally to an average elevation of $4200 \mathrm{~m}$ a.s.l. in summer (Carrasco et al., 2005). Most areas up to $3900 \mathrm{~m}$ a.s.l. become snow-free until year-end, and only small snow patches related to snow redistribution last longer and may persist (Bodin et al., 2010a; Apaloo et al., 2012). Vegetation is completely absent above $\sim 3200 \mathrm{~m}$ a.s.l. Only small patches of high Andean steppe vegetation exist above $\sim 3000$ m a.s.l.

Strong downwasting and widening of thermokarst depressions on debris-covered glaciers has been observed in the study area (Bodin et al., 2010a). Exposures in melt-out depressions show debris-cover thicknesses of $\sim 1$ to $\sim 1.5 \mathrm{~m}$ on the surfaces of both debris-covered glaciers in the study area, which show a transition into uncovered glaciers in their upper parts.

The study area presents mainly dark volcanic rocks of the Tertiary Abanico Formation. A granodioritic intrusive unit is present in the northwestern corner of the study area, and volcanic and sedimentary sequences of the Late Cretassic Colimapu Formation occupy the eastern margin of the study area (Fock et al., 2005; Farías et al., 2008). All data logger locations are in the dark volcanic area, while a small percentage $(<10 \%)$ of the matched samples introduced in Sect. 3.6 are located in the other geological units.

\subsection{Image acquisition}

Two ASTER (Advanced Spaceborne Thermal Emission and Reflection Radiometer) scenes of the study area were obtained for this study from the Earth Remote Sensing Data Analysis Center, one acquired at nighttime and one at daytime. ASTER was selected not only because of its high spatial resolution, but also its wide spectral range of the shortwave infrared and thermal infrared spectra, which were used for deriving albedo, LST, and ATI. 


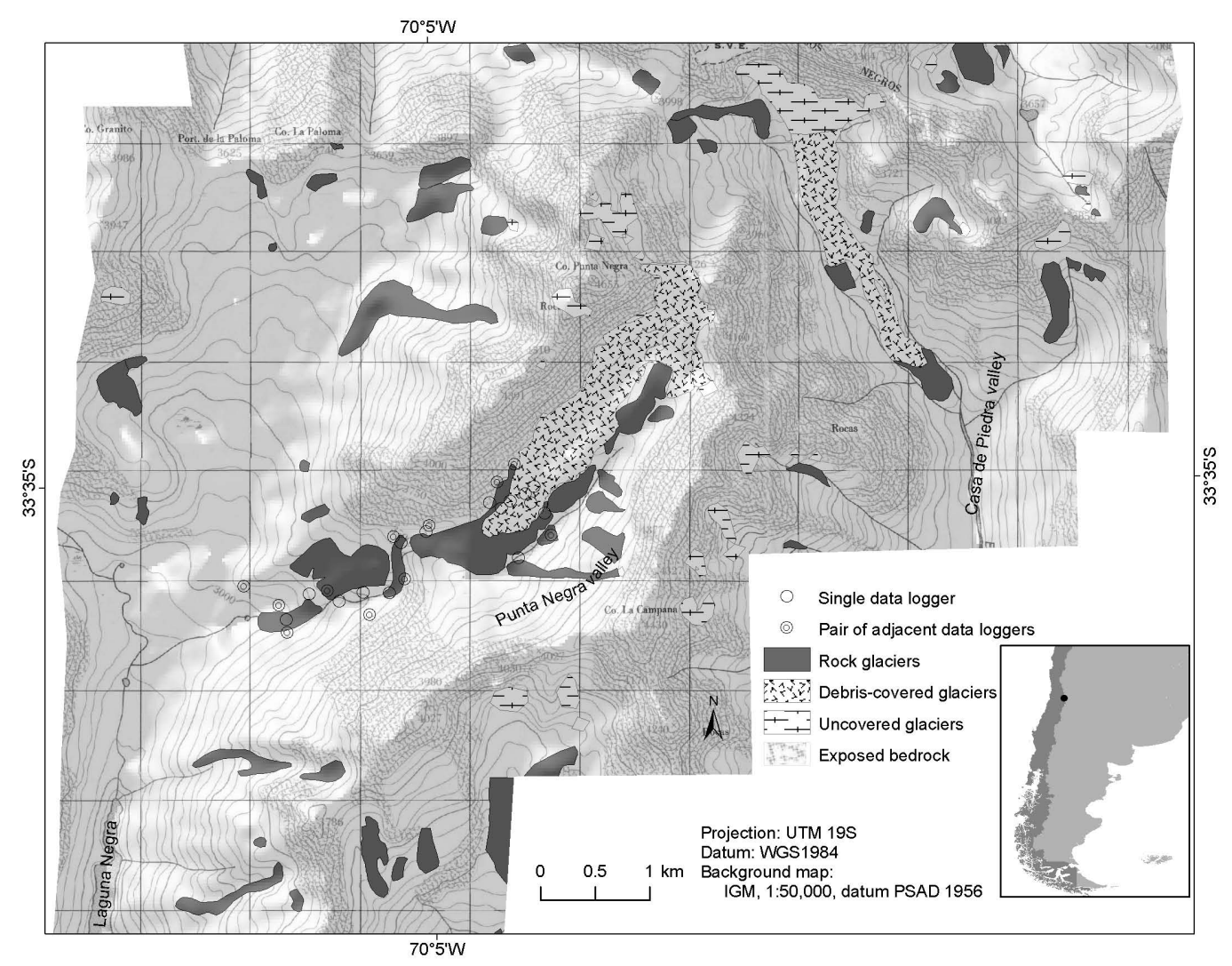

Fig. 1. Study area with ice-debris landforms and data logger locations.

ASTER is an imaging instrument aboard the Terra satellite, launched in 1999, which is part of NASA's Earth Observing System. The ASTER sensor is comprised of 14 spectral channels ranging from the visible to thermal infrared spectrum $(0.52$ to $11.65 \mu \mathrm{m})$, including 3 bands in the visible and near-Infrared spectrum (VNIR, $15 \mathrm{~m}$ spatial resolution), 6 in the shortwave infrared spectrum (SWIR, $30 \mathrm{~m}$ ), and 5 in thermal infrared (TIR, $90 \mathrm{~m}$ ).

In consideration of the accuracy and reliability of the study, a pair of nighttime and daytime ASTER scenes was selected that minimizes snow and cloud cover, was acquired within the smallest possible time period and during a period with stable meteorological conditions. Only images acquired prior to 23 April 2008 were eligible because the ASTER's SWIR detector has been defective since then (ASTER Science Office, 2009). As a result, the daytime scene selected was acquired on 30 March 2008 at local solar time 14:44, and the nighttime scene on 1 April 2008 at local solar time 3:31. Cloud cover was $1 \%$ and $2 \%$ respectively, but did not affect the study area, and snow cover was at its seasonal minimum extent. Meteorological conditions are described in Sect. 3.4 in detail.

Both ASTER scenes acquired are geometrically corrected and radiometrically calibrated level $1 \mathrm{~B}$ products. For the following processing steps, the data was orthorectified based on
10 pairs of manually selected control points and ASTER GDEM (source: Earth Remote Sensing Data Analysis Center; resolution 1") using PCI Geomatica 10 OrthoEngine. The imagery was atmospherically corrected using the FLAASH (Fast Line-of-Sight Atmospheric Analysis of Spectral Hypercubes) module of ENVI, which incorporates the standard MODTRAN (Moderate Resolution Atmospheric Transmission) model atmosphere and aerosol types to represent the scene to be corrected. FLAASH reduces the haze (or scattered-path radiance) and adjacency effects that distort the image pixel radiance, and at the same it models the at-surface irradiance. The outputs are reflectances free of atmospheric distortions, i.e. apparent surface reflectances. Due to the lack of suitable data describing the angular distribution of radiation, no attempt was made to further correct these output reflectance values for their anisotropic reflection However, a possible influence of anisotropic reflection on statistical results was assessed in a post-hoc analysis.

\subsection{Derivation of albedo and thermal variables}

In order to estimate daytime and nighttime LST (LST day, $\mathrm{LST}_{\text {night }}$ ) and ATI from ASTER data, albedo and emissivity first need to be calculated. Surface albedo was derived from the reflection bands (bands 1-9) of the ASTER daytime 


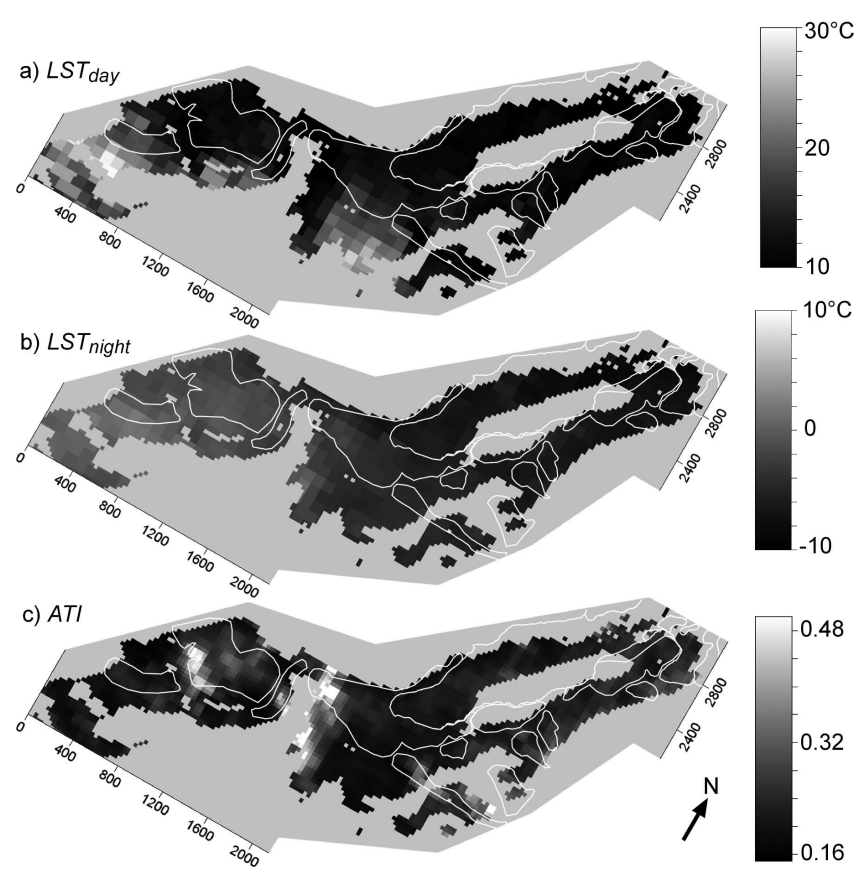

Fig. 2. Maps of (a) $L S T_{\text {day }}$, (b) $L S T_{\text {night }}$, (c) $A T I$ in the Punta Negra valley. Grey background areas correspond to masked areas.

dataset. The apparent surface reflectances of most of the reflection bands (i.e. narrowband albedos) were converted to broadband albedo using

$$
\begin{aligned}
a & =0.484 a_{1}+0.335 a_{3}-0.324 a_{5}+0.551 a_{6} \\
& +0.305 a_{8}-0.367 a_{9}-0.0015
\end{aligned}
$$

where $a$ is the broadband albedo, and $a_{1}, \ldots, a_{9}$ are the narrowband albedos (Liang, 2000). Surface albedo values obtained for uncovered glaciers, lake surfaces and high Andean steppe vegetation within or near our study area agree well with typical values reported in the literature for comparable surface types (Table 1; Knap et al., 1999; Geiger et al., 2003). Vegetation-free surfaces such as morainic debris, rock glaciers and talus slopes had agreeable average albedo values around 0.09 due to the dark volcanic rocks present in the study area.

LST was derived from the TIR bands using the Normalized Emissivity Method (Gillespie, 1986; Realmuto 1990). Apparent surface temperatures, $T_{b}[\mathrm{~K}]$, were first calculated for each TIR band $b$ using an assumed maximum emissivity $\varepsilon_{\max }=0.965$ :

$T_{b}=\frac{C_{2}}{\lambda}\left(\ln \left(\frac{C_{1} \varepsilon_{\max }}{\pi R_{b} \lambda_{b}^{5}}+1\right)\right)^{-1}$

where $C_{1}=3.74151 \times 10^{-16}$ and $C_{2}=0.0143879 \mathrm{mK}$ are constants from Planck's Law, $\lambda_{b}[\mu \mathrm{m}]$ is the wavelength of emitted radiance for a thermal band, and $R_{b}$ $\left[\mathrm{Wm}^{-2} \mathrm{sr}^{-1} \mu \mathrm{m}^{-1}\right]$ is the emitted radiance for a thermal band. The highest of these was then selected as the LST under the assumption that the true maximum emissivity occurs in the band for which the maximum $T_{b}$ is calculated:

$\mathrm{LST}=\max _{b}\left(T_{b}\right)$

Based on $\mathrm{LST}_{\text {day }}$ and $\mathrm{LST}_{\text {night }}$ calculated in this way from daytime and nighttime scenes, we calculated ATI as a practical proxy for thermal inertia based on Eq. (3) and utilizing remotely-sensed estimates in Eqs. (4) and (6) of the variables involved (Fig. 2):

$$
\mathrm{ATI}=\frac{(1-a) \mathrm{PISR}}{\mathrm{LST}_{\text {day }}-\mathrm{LST}_{\text {night }}}
$$

where PISR is the potential incoming shortwave radiation on the day of image acquisition up to the time of image acquisition, derived from ASTER G-DEM as described in Sect. 3.6.

\subsection{Meteorological conditions}

Image acquisition was near the end of the dry summer season. At the Embalse El Yeso weather station (EEY; $33^{\circ} 40^{\prime} \mathrm{S}$, $70^{\circ} 05^{\prime} \mathrm{W}, 2475 \mathrm{~m}$ a.s.l.) $9 \mathrm{~km}$ south of the core study area, $503 \mathrm{~mm}$ water equivalent (w.e.) of precipitation were registered during the 12 months preceding image acquisition, which is close to the 1961-1992 climatic average, suggesting a normal snow extent (data source: Dirección General de Aguas, DGA). The March 2008 mean temperature at EEY was $15.1^{\circ} \mathrm{C}$ (climatic average: $13.6^{\circ} \mathrm{C}$ ). The last precipitation events at EEY occurred during the 6-10 March period, totalling $34 \mathrm{~mm}$ w.e. (climatic average of March: $7 \mathrm{~mm}$ w.e.), presumably leaving only a temporary snow cover for a few days. Daily mean temperatures during this period averaged $13.4^{\circ} \mathrm{C}$ at EEY and increased significantly during the following days, peaking at $17.0^{\circ} \mathrm{C}$ at EEY on 13 March (daily maximum $21.4^{\circ} \mathrm{C}$ ).

Sunshine duration at EEY was at its local astronomical/topographic maximum of $9.0-9.5 \mathrm{~h}$ per day during the two-week period preceding the last image acquisition, with the exception of $24 \mathrm{March}$, with only $2.6 \mathrm{~h}$ sunshine, and 31 March, with $7.0 \mathrm{~h}$ of sunshine. From 20 March on, daily maximum temperatures at EEY decreased steadily from $\sim 23-25^{\circ} \mathrm{C}$ to $18.0^{\circ} \mathrm{C}$ on 29 and 30 March, while minimum temperatures dropped from $\sim 10-11^{\circ} \mathrm{C}$ to $6-7^{\circ} \mathrm{C}$ during the same period. Daily amplitudes ranged between $\sim 10$ and $12{ }^{\circ} \mathrm{C}$. The daily maximum on 30 March (daytime image acquisition) was $18.0^{\circ} \mathrm{C}$ (minimum: $6.0^{\circ} \mathrm{C}$ ), followed by a less variable day $\left(17.2^{\circ} \mathrm{C}\right.$ maximum, $7.2^{\circ} \mathrm{C}$ minimum) at EEY, which is consistent with the reduced sunshine duration indicating some cloud cover during that day. Minimum temperature on 1 April (nighttime image acquisition) was $5.6^{\circ} \mathrm{C}$, with a maximum temperature of $18^{\circ} \mathrm{C}$ and $9.0 \mathrm{~h}$ sunshine, resembling very much the air temperature conditions on the day of the daytime image acquisition. The observed minimum temperatures are close to the mean value for April $2008\left(5.6^{\circ} \mathrm{C}\right)$, while the maximum is closer to the average 
Table 1. ASTER-derived broadband surface albedo values of selected homogeneous test surfaces in and near the study area.

\begin{tabular}{|c|c|c|c|}
\hline Surface type & Location & Mean albedo & $\begin{array}{l}\text { Standard } \\
\text { deviation }\end{array}$ \\
\hline Old snow & Accumulation area of Mesón Alto glacier & 0.516 & 0.006 \\
\hline Old snow, glacier ice & Punta Negra glacier, debris-free part & 0.460 & 0.051 \\
\hline Debris-covered glacier & Punta Negra glacier & 0.099 & 0.013 \\
\hline Debris-covered glacier & Casa de Piedra glacier & 0.090 & 0.019 \\
\hline Talus slope, dark rock, no vegetation & Punta Negra valley & 0.098 & 0.018 \\
\hline Talus slope, dark rock, no vegetation & Casa de Piedra valley ${ }^{a}$ & 0.070 & 0.006 \\
\hline Alluvial fan, dark rock, no vegetation & Casa de Piedra valley ${ }^{a}$ & 0.115 & 0.010 \\
\hline Granodioritic rock deposit, fines to large blocks, sparse vegetation & Mesón Alto (prehistoric) rockslide & 0.174 & 0.038 \\
\hline Fluvial terrace with sparse vegetation, diverse magmatic and sedimentary rocks & Yeso valley & 0.138 & 0.006 \\
\hline Wetland, vegetation partly dried out in fall & Yeso valley & 0.102 & 0.009 \\
\hline Reservoir, deep and large & El Yeso reservoir & 0.047 & 0.004 \\
\hline Lake, deep and large, wind-sheltered & Laguna Negra & 0.028 & 0.002 \\
\hline
\end{tabular}

a Opposite valley sides with rock types from different geological formations.

March 2008 daily maximum of $19.0^{\circ} \mathrm{C}$ (April: $16.2^{\circ} \mathrm{C}$ ) at $\mathrm{EEY}$, reflecting again the cloud-free conditions on the acquisition dates.

Overall, the image acquisition days can be characterized as typical of this time of the year in terms of temperature distribution, cloud-free skies, and prolonged lack of precipitation. A slight perturbation of these conditions occurred on the day between the image acquisitions, and is related to approximately two hours of daytime cloud cover at EEY.

\subsection{Field observations}

We relate LST and thermal inertia to NSGT measurements at 37 locations on debris surfaces and ice-debris landforms in the Punta Negra valley (Fig. 1; details in Apaloo et al., 2012). Hourly NSGT measurements were obtained using one- and two-channel Onset Hobo data loggers installed at $\sim 5 \mathrm{~cm}$ depth below the ground surface (Onset Hobo U23004 and H08-032 Pro, accuracy $0.2^{\circ} \mathrm{C}$, resolution 0.02 and $0.03^{\circ} \mathrm{C}$, respectively). Locations were chosen to provide a balanced, roughly stratified sample of different classes of elevation, modeled potential incoming solar radiation (PISR, see Sect. 3.6), and presence of long-lasting snow patches, most sites being paired with respect to the latter local control. Various site conditions of the logger sites, located between 3028 and $3776 \mathrm{~m}$ a.s.l., were recorded in the field. This included the presence of a coarse blocky substrate (0/1-variable COARSE; $1=$ coarse material), or whether the site was located on an ice-debris accumulation (0/1-variable RDG; $1=$ on ice-debris accumulation). Rock glaciers and debriscovered glaciers were not distinguished in the statistical analysis of logger data because of sample size limitations.

Since suitable ASTER imagery was not available during the NSGT observation period, a time period with similar meteorological conditions as at the acquisition time was used, as described below; we refer to this period (27-30 March 2009) as the "reference period". Clearly, both the temporal mismatch between image acquisition and in-situ measurements and, even more so, the difference in spatial scale will introduce uncertainties that may weaken correlations between remotely-sensed and in-situ observations.

The following thermal attributes were extracted from the NSGT time series for statistical analysis:

- Mean annual NSGT from 1 March 2009 until 28 February 2011 (MANSGT);

- average daily minimum and maximum NSGT (NSGT $_{\min }, \mathrm{NSGT}_{\max }, \mathrm{NSGT}_{\text {mean }}$ ) and mean daily NSGT amplitude (NSGT $a m p$ ) during the four-day reference period.

In addition, air temperature was measured at 32 of the 37 locations at $50 \mathrm{~cm}$ above the ground.

The reference period was selected by comparing sunshine duration and air temperatures at EEY at the end of March and beginning of April 2009 and 2010 with the conditions observed during the image acquisition period. The selected four-day period from 27 to 30 March 2009 had similar sunshine duration (EEY: astronomical-topographic maximum of 9.1-9.2 hours on three days, 8.0 hours on one day) and a similar temperature amplitude (average: $12.2^{\circ} \mathrm{C}$ ), although minimum and maximum air temperatures at $\mathrm{EEY}\left(8.8^{\circ} \mathrm{C}\right.$ and $21.0^{\circ} \mathrm{C}$, respectively, on average) were $\sim 3^{\circ} \mathrm{C}$ warmer than during the 30 March to 1 April 2008 image acquisition period. NSGT variations at the logger sites during and prior to the reference period are shown in Fig. 3.

During the reference period, average daily minimum NSGT at the logger sites ranged from $-0.8^{\circ} \mathrm{C}$ to $+12.1^{\circ} \mathrm{C}$ (average daily maxima: $6.2-31.9^{\circ} \mathrm{C}$ ), and air temperatures at $50 \mathrm{~cm}$ above ground reached daily minima of $0.2-6.4^{\circ} \mathrm{C}$ (daily maxima: $9.7-24.3^{\circ} \mathrm{C}$ ) on average. The cooler EEY temperatures during the acquisition period suggest that the nighttime ZIA of the free atmosphere was likely around 3200-3400 $\mathrm{m}$ a.s.l. during image acquisition. 

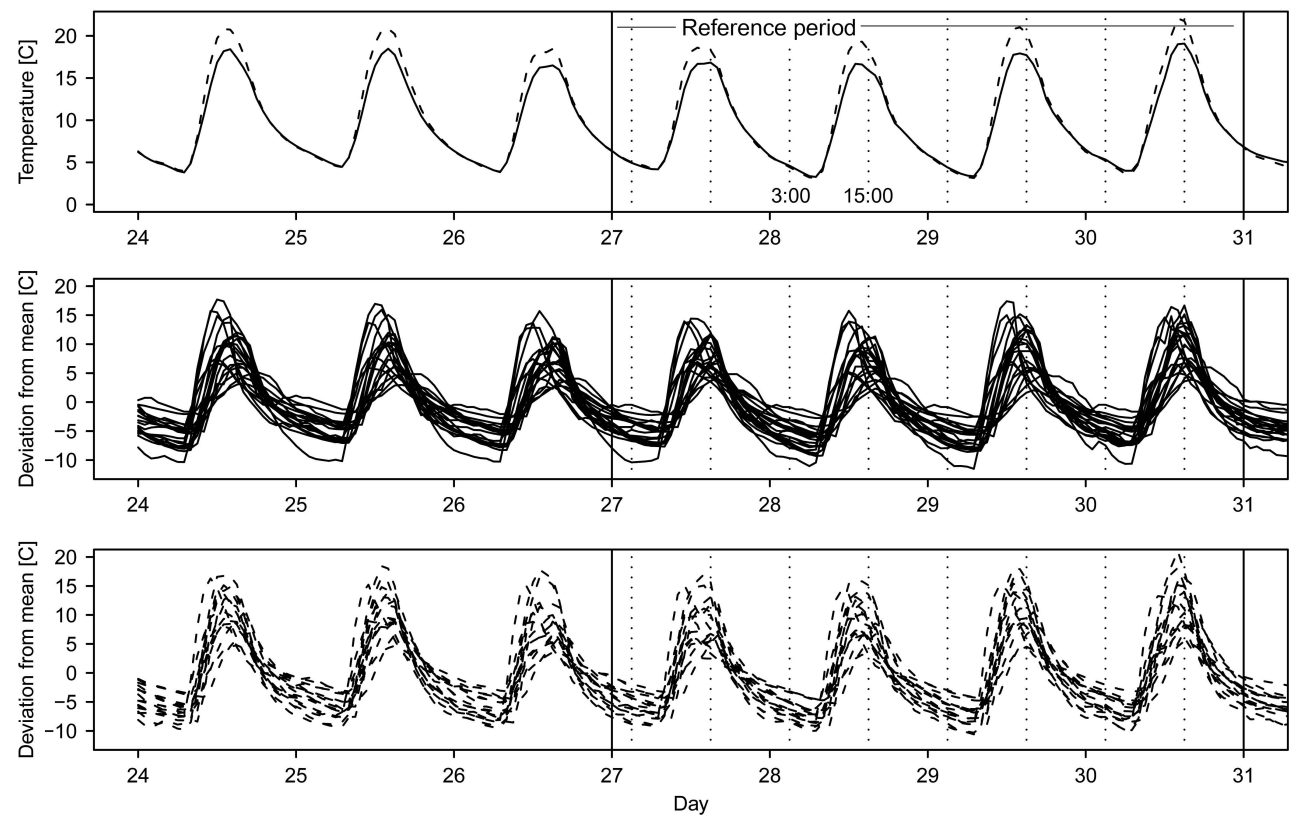

Fig. 3. Hourly NSGT time series at logger sites for location outside (solid lines) and within ice-debris landforms (dashed lines) during the 24-30 March 2009 period. The upper panel shows average NSGTs of all data loggers, the lower panels individual logger time series as deviation from each logger's mean NSGT. The reference period is delimited by continuous vertical lines; dotted lines indicate times of daytime and nighttime NSGT readings (3 p.m., 3 a.m.).

Geomorphological and cryospheric mapping, including presence/absence information on rock glaciers and debriscovered glaciers in the area, was furthermore conducted in the field and based on orthorectified IKONOS imagery (panchromatic resolution: $1 \mathrm{~m} \times 1 \mathrm{~m}$; GeoEye / Pacific Geomatics Ltd.). The study area covers $48 \mathrm{~km}^{2}$ between 3000 and $3900 \mathrm{~m}$ a.s.l., of which $4.9 \mathrm{~km}^{2}$ correspond to ice-debris landforms (rock glaciers: $3.3 \mathrm{~km}^{2}$ ). The area of interest is reduced to $21 \mathrm{~km}^{2}$ after removing irrelevant areas such as exposed ice and bedrock. More than 50 rock glaciers are present in the study area, the exact number depending on how multi-part rock glaciers are counted. All rock glaciers included in this study are considered to be intact, and all but a few smaller rock glaciers below $3200 \mathrm{~m}$ a.s.l. are likely active based on morphological criteria (Brenning, 2005a, b; Bodin et al., 2010a). Differential GPS measurements on two morphologically active features confirmed their activity (Bodin et al., 2010b).

\subsection{Statistical analysis}

Our statistical analyses are of exploratory character, i.e. they aim at discovering novel relationships rather than confirming an existing hypothesis. Linear mixed-effects models that account for grouped sampling were used for this purpose, and the false-discovery rate (FDR) was controlled in performing multiple hypothesis tests.
Two different samples are considered. The first one corresponds to the logger sites described in Sect. 3.5, which allows us to correlate the remotely-sensed variables with NSGT variables as well as local site conditions observed in situ. This has the disadvantage that logger sites constitute a rather small sample of point observations with a limited spatial representativity, while the remotely-sensed variables were derived by combining spectral bands measured at resolutions ranging from $15 \mathrm{~m} \times 15 \mathrm{~m}$ to $90 \mathrm{~m} \times 90 \mathrm{~m}$.

The second sample avoids these problems by sampling grid cells directly from the remotely-sensed imagery, but this approach is limited to the assessment of elevation and PISRrelated influences and comparisons between sites with rock glaciers or debris-covered glaciers versus rock debris surfaces. First, grid cells located within digitized ice-debris landforms were randomly sampled, using an upper elevation limit of $3900 \mathrm{~m}$ a.s.l. Debris-surface grid cells were then matched to these samples as controls based on slope angle (tolerance $\left.\pm 5^{\circ}\right)$, PISR on the acquisition date $( \pm 10 \%)$, albedo $( \pm 5 \%)$ and elevation $( \pm 50 \mathrm{~m})$. Where multiple matches were available, the most similar one (according to a weighted sum of the mentioned four variables) was selected. Matching ensures that several components of the surface energy balance in Eq. (1) are controlled and do not affect the comparison of ATI between ice-debris landforms and debris surfaces, which is one of our main objectives. Specifically, differences in net short wave radiation are accounted for by matching by albedo and PISR, and upwelling 
long wave radiation is controlled by the elevation variable. The final matched random sample consisted of 1000 grid cells, 379 of which corresponded to rock glacier and 121 to debris-covered glacier areas.

Elevation, slope angle and potential incoming solar radiation for the acquisition date of the daytime image were derived from ASTER G-DEM elevation data (Hayakawa et al., 2008). In the matched-sample analysis, exposed bedrock areas were masked using a combination of topographic criteria and bedrock areas digitized from a topographic map (Instituto Geográfico Militar, scale 1:50,000). Areas with albedo $a<0.05$ or $a>0.20$ or ATI $>0.60$ were removed in order to avoid artifacts resulting from mixed pixels involving fractional snow cover, melt-out ponds or other local phenomena with thermophysical characteristics that may bias the coefficient estimates. The rather low albedo cut-off value of 0.20 is due to the prevailing low albedo of dark volcanic rocks (Table 1). Only $3.6 \%$ of the samples obtained in the previous filtering steps were removed based on their extreme albedo or ATI values.

Linear mixed-effects models were used to analyze both samples. $\mathrm{LST}_{\text {day }}, \mathrm{LST}_{\text {night }}, \mathrm{LST}_{\mathrm{amp}}$ and ATI were used as response variables in both samples, and in the case of the logger sites also $\mathrm{NSGT}_{\text {day }}, \mathrm{NSGT}_{\text {night }}, \mathrm{NSGT}_{\text {amp }}$ and MANSGT. Elevation above $3000 \mathrm{~m}$ a.s.l. $\left(\mathrm{ELEV}_{3000}\right)$ and PISR on the acquisition date (relative to the area-wide average; $r$ PISR $=$ PISR $/$ mean PISR -1 ) were incorporated in models for LST, but not for ATI, which was solar-corrected in Eq. (3). All-day PISR was used for this in the case of analyses of $\mathrm{LST}_{\text {night }}$, and PISR up to the acquisition time ( $3 \mathrm{pm}$ local time) otherwise (variable $\mathrm{rPISR}_{p}$ ). In addition, $0 / 1$-variables for the presence of rock glaciers $(R G L)$ and debris-covered glaciers (DGL; $1=$ presence) were included in the case of matched-sample data, and 0/1-variables for ice-debris landforms (RDG; $1=$ presence of rock glacier or debris-covered glacier) and for the presence of coarse blocky material (COARSE) were tested on the logger data set. No attempt was made to distinguish between rock glacier and debris-covered glacier sites in the analysis of logger data because of the small sample size. Descriptive statistics of the response variables and site characteristics are summarized in Table 2.

In this model, PISR and elevation account for short and long wave radiation controls on the surface energy balance, respectively, while the ice-debris landform and coarseness variables are proxies for specific properties influencing the ground flux. Turbulent heat fluxes are, however, not accounted for due to the unknown spatial characteristics of the wind field.

The grouping of logger sites was used as a random-effect term on the intercept in the case of the logger sample, while the grouping in matched pairs defined a random effect on the intercept in the matched-sample analysis. In the matchedsample analysis, a spherical spatial autocorrelation structure with nugget effect was used initially to account for possible residual spatial dependence, but the fitted nugget autocorrelation was consistently near 1 , which means that no spatial autocorrelation was present after accounting for the paired grouping. Spatial autocorrelation was therefore omitted from the final models.

In addition to this main approach, post-hoc analyses were performed to examine the sensitivity of the results to several possible confounders and uncertainties. These include the choice of the reference period, different PISR parameterizations, and the additional incorporation of sine and cosine of aspect into the model to control possible influences of anisotropic reflection.

The potential utility of ATI for discriminating rock glaciers and other ice-debris landforms was assessed using the area under the receiver operating characteristics (ROC) curve, or AUROC, which takes values between 0.5 (no discrimination) and 1.0 (perfect discrimination).

Given the small sample size and large number of statistical hypothesis tests performed for exploratory purposes, we applied a correction for multiple testing that controls the FDR of the family of tests. The FDR is the proportion of false positive hypothesis tests among all positive test outcomes. We controlled the FDR at the $\leq 10 \%$ level, i.e. we expect that of all positive test outcomes reported in this study, no more than $10 \%$ were incorrectly classified as positive. The Simes procedure was used for this correction (Benjamini and Hochberg, 1995).

All statistical analyses were conducted in the software R (version 2.11.1; R Development Core Team, 2010) with its contributed packages "nlme" (Pinheiro et al., 2009) and "ROCR" (Sing et al., 2009), and terrain analysis and geodata processing were conducted with SAGA GIS (version 2.0.4; Conrad, 2006) and the "RSAGA" package for R (Brenning, 2008).

\section{Results}

After assessing to what extent the remotely-sensed observations of thermal and thermophysical variables are related to in-situ measurements (Sect. 4.1), we then explore and interpret empirical relationships of these variables with respect to geomorphic and climatic site characteristics using statistical models (Sect. 4.2).

\subsection{Relationships between remotely-sensed and in-situ variables}

Remotely-sensed and in-situ measurements of daytime and nighttime surface temperatures at the logger sites $(N=37)$ correlated reasonably well ( $\rho=0.83$ at nighttime and 0.49 at daytime; Table 3 ). Median nighttime and daytime NSGT during the reference period were, however, $6-7^{\circ} \mathrm{C}$ higher than LST at the logger sites (Table 2). This can be partly explained by $3{ }^{\circ} \mathrm{C}$ higher air temperatures during the reference 
Table 2. Descriptive statistics of remotely-sensed and in-situ variables and site characteristics at the logger sites and in the matched random sample.

\begin{tabular}{lll}
\hline Variable & Logger sites Median (IQR) & Matched sample Median (IQR) \\
\hline Remotely-sensed variables & & \\
$L S T_{\text {day }}\left[{ }^{\circ} \mathrm{C}\right]$ & $12.2(7.1)$ & $14.9(5.9)$ \\
$L S T_{\text {night }}\left[{ }^{\circ} \mathrm{C}\right]$ & $-1.2(5.5)$ & $-1.1(3.2)$ \\
$L S T_{\text {amp }}\left[{ }^{\circ} \mathrm{C}\right]$ & $16.3(7.3)$ & $16.3(5.6)$ \\
$A T I[-]$ & $0.26(0.05)$ & $0.25(0.08)$ \\
Albedo $[-]$ & $0.091(0.029)$ & $0.093(0.025)$ \\
In-situ variables & & \\
$N S G T_{\text {day }}\left[{ }^{\circ} \mathrm{C}\right]$ & $19.3(8.9)$ & - \\
$N S G T_{\text {night }}\left[{ }^{\circ} \mathrm{C}\right]$ & $4.5(5.0)$ & - \\
$N S G T_{\text {amp }}\left[{ }^{\circ} \mathrm{C}\right]$ & $13.3(8.2)$ & - \\
$M A N S G T\left[{ }^{\circ} \mathrm{C}\right]$ & $2.9(4.9)$ & \\
Site characteristics & & $3479(331)$ \\
Elevation $[\mathrm{m}$ a.s.l. & $3466(462)$ & $0.00(0.23)$ \\
$r P I S R[-]$ & $0.01(0.24)$ & $0.01(0.17)$ \\
$r P I S R_{p}[-]$ & $0.02(0.14)$ & $15.1(8.8)$ \\
Slope angle $\left[{ }^{\circ}\right]$ & $20.5(16.9)$ & \\
\hline
\end{tabular}

period, and it may also reflect possible differences in turbulent heat fluxes or a bias in LST measurements relative to NSGT, which was measured at about $5 \mathrm{~cm}$ depth and at a point scale.

The strongest association between remotely-sensed and in-situ variables measured was found for $\mathrm{LST}_{\text {night }}$, which was strongly correlated $(\rho>0.80)$ with $\mathrm{NSGT}_{\text {night }}$ and MANSGT, and slightly less strongly with $\mathrm{NSGT}_{\text {day }}$ (Table 3). The strong correlation of LST $_{\text {night }}$ is explained by the spatial homogeneity of surface temperature during night as controlled by kinetic temperature, surface emissivity and incoming long wave radiation, which yield a better correspondence between point measurements (loggers) and area measurements (ASTER pixels). The spatially much more variable $\mathrm{LST}_{\text {day }}$, in contrast, was moderately correlated with these three in-situ temperature variables $(\rho \approx 0.50)$. $\mathrm{LST}_{\text {amp }}$ and ATI were only weakly and not significantly correlated with in-situ thermal variables. The weak (but significant) positive(!) correlation between $\mathrm{LST}_{\text {night }}$ and $\mathrm{NSGT}_{\text {amp }}$ is likely a random association. Although the fixed NSGT readings at 3 a.m. and 3 p.m. used for calculating $\mathrm{NSGT}_{\text {night }}$ and NSGT $_{\text {day }}$ do not exactly represent the time of minimum and maximum NSGT (Fig. 3), neither these correlations nor any of the further statistical analyses in this study appear to be sensitive to whether these fixed readings or actual NSGT minima and maxima are used.

The correlations between LST and NSGT during the day and at night reflect to a large extent the presence of general altitudinal trends in temperature. When looking only at local temperature variation by removing a linear altitudinal trend, much weaker, non-significant positive correlations
Table 3. Correlation of remotely-sensed variables with in-situ variables at the logger sites. Spearman correlation coefficients and tests, non-significant associations in square brackets; FDR controlled at $\leq$ $10 \%$.

\begin{tabular}{lllll}
\hline Variable & $L S T_{\text {day }}$ & $L S T_{\text {night }}$ & $L S T_{\text {amp }}$ & $A T I$ \\
\hline$N S G T_{\text {day }}$ & 0.49 & 0.75 & {$[0.24]$} & {$[0.03]$} \\
$N S G T_{\text {night }}$ & 0.47 & 0.83 & {$[0.14]$} & {$[-0.14]$} \\
$N S G T_{\text {amp }}$ & 0.33 & 0.40 & {$[0.22]$} & {$[0.14]$} \\
$M A N S G T$ & 0.52 & 0.89 & {$[0.18]$} & {$[-0.11]$} \\
\hline
\end{tabular}

Table 4. Correlation of detrended remotely-sensed variables with detrended in-situ variables at the logger sites. Variables were detrended by resting each variable's linear trend with elevation. Spearman correlation coefficients and tests, non-significant associations in square brackets; FDR controlled at $\leq 10 \%$.

\begin{tabular}{lll}
\hline Variable & $d L S T_{\text {day }}$ & $d L S T_{\text {night }}$ \\
\hline$d N S G T_{\text {day }}$ & {$[0.25]$} & {$[0.26]$} \\
$d N S G T_{\text {night }}$ & {$[0.08]$} & {$[0.20]$} \\
$d M A N S G T$ & {$[0.12]$} & {$[0.10]$} \\
\hline
\end{tabular}

remain (Table 4). The weakness and non-significance of this relationship can partly be attributed to the small sample size and decorrelation of remotely-sensed and in-situ data due to temporal and scale differences. However, the consistently positive correlations suggest that remotely-sensed LST does 
provide insights into local spatial patterns of NSGT other than those related to a simple altitudinal lapse rate. As an $a d$ hoc example, a $1^{\circ} \mathrm{C}$ difference in $\mathrm{dLST}_{\text {night }}$ predicts a $0.5^{\circ} \mathrm{C}$ difference in $\mathrm{NSGT}_{\text {night }}$ according to a linear mixed-effects model relating $\mathrm{NSGT}_{\text {night }}$ to $\mathrm{ELEV}_{3000}$ and $\mathrm{dLST}_{\text {night }}$, which has a standard deviation of $0.9^{\circ} \mathrm{C}$. While this trend estimate has a large uncertainty (standard error $0.3^{\circ} \mathrm{C}$ ), it gives us an idea of the contribution that remotely-sensed LST can make to explain local variation in the thermal state of the dry ground surface in mountain areas during the snow-free period.

\subsection{Relationships with site characteristics}

Daytime and nighttime LST in the matched sample were strongly related to elevation as a proxy for atmospheric temperatures and $\mathrm{rPISR}_{p}$ as a proxy for radiative controls (Table 5). $\mathrm{rPISR}_{p}$ influenced $\mathrm{LST}_{\text {day }}$ much more strongly than rPISR did for $\mathrm{LST}_{\text {night }}$, which is plausible because daytime surface temperatures are controlled mainly by absorption of incoming solar radiation while nighttime temperatures are controlled by emission of heat. In the case of a one-IQR (interquartile range) difference in solar radiation, a $3.1^{\circ} \mathrm{C}$ difference in $\mathrm{LST}_{\text {day }}$ would be predicted compared to a $0.9^{\circ} \mathrm{C}$ difference at night, all other variables being equal. The LST amplitude mirrored the $\mathrm{LST}_{\text {day }}$ situation as it most strongly depended on the more variable daytime temperature. Over the entire study area, model-derived LST lapse rates were in good agreement with a dry adiabatic lapse rate of air temperature.

Empirical relationships found for the logger sites in the Punta Negra valley appear to differ in some important aspects; however, the observations for this smaller sample are also subject to substantial uncertainties and random variation related to site selection and instrumentation. At the logger sites, the model-derived LST and NSGT lapse rates were close to the dry adiabatic lapse rate of $-1{ }^{\circ} \mathrm{C} / 100 \mathrm{~m}$ at nighttime but were clearly stronger at daytime $(\sim-1.5-$ $-2{ }^{\circ} \mathrm{C} / 100 \mathrm{~m}$ ). Near-surface air temperatures at $50 \mathrm{~cm}$ above ground showed a similar daytime lapse rate during the reference period $\left(-1.50^{\circ} \mathrm{C} / 100 \mathrm{~m}\right.$, standard error $\left.0.09^{\circ} \mathrm{C} / 100 \mathrm{~m}\right)$.

Ice-debris landforms in the matched-sample analysis had a lower $\operatorname{LST}_{\text {day }}\left(\sim 1-1.5^{\circ} \mathrm{C}\right.$ lower $)$ and therefore also a smaller $\mathrm{LST}_{\text {amp }}\left(\sim 1-2^{\circ} \mathrm{C}\right.$ smaller $)$. In the case of rock glaciers, this resulted in an ATI being $13 \%$ higher than in non-rock glacier areas under otherwise equal conditions (Table 5). These differences were somewhat weaker in debris-covered glacier areas compared to rock glaciers, and ATI on debriscovered glaciers was not significantly different from general debris surfaces under otherwise equal conditions. However, a post-hoc analysis using slope aspect to account for possible anisotropic reflection resulted in a greater estimate of the daytime temperature anomaly and ATI increase of debris-covered glaciers $\left(\mathrm{LST}_{\text {day }} 2.53^{\circ} \mathrm{C}\right.$ lower under otherwise equal conditions, standard error: $0.37^{\circ} \mathrm{C}$, unadjusted p-value <0.001; ATI 0.034 higher, standard error 0.006, unadjusted p-value $<0.001$ ) while post-hoc coefficient estimates for the rock glaciers remained within the confidence limits of coefficients reported in Table 5.

LST at the logger sites showed a (non-significant) negative daytime anomaly on ice-debris landforms, as well as a similar negative anomaly on coarse blocky surfaces (on ice-debris landforms as well as outside of these). However, it should be noted that the local observation of the presence/absence of coarse blocky material at the logger's point location may not be representative of the area covered by the corresponding ASTER grid cell.

While the logger-site LST observations on ice-debris landforms also showed a (non-significant) negative anomaly for daytime (and nighttime) LST, the observed (marginally significant) positive NSGT anomaly at daytime $\left(+3.66^{\circ} \mathrm{C}\right)$ was inconsistent with this. This positive daytime NSGT anomaly on ice-debris landforms was reproducible under 5-fold crossvalidation resampling and therefore cannot be attributed to influential outliers, even though the positive anomaly drops to (non-significant) $+2.61{ }^{\circ} \mathrm{C}$ (standard error $1.12^{\circ} \mathrm{C}$ ) if two samples showing strongest disagreement between $\mathrm{LST}_{\text {day }}$

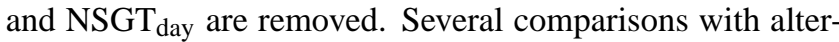
native reference periods during February/March 2009/2010 also indicate that this anomaly appears to be a persistent pattern during the 2009 summer / early fall period even though it tended to be less pronounced than during the selected reference period. It therefore had an effect on MANSGT under otherwise equal conditions, even when controlling for differences in snow cover duration (Apaloo et al., 2012).

The observed differences in mean ATI between the surfaces of ice-debris landforms and other debris surfaces can also be expressed with regards to the capability of the ATI to discriminate between these surface types. The resulting AUROC values show, overall, a "fair" discrimination (Table 6), but this would not be sufficient to delineate ice-debris landforms based on an ATI threshold alone.

Generally speaking, all results related to NSGT measurements reproduced very well in comparison with similar alternative reference periods during February/March of 2009/2010. Coefficient estimates and correlation coefficients were well within the uncertainties given by estimated standard errors. Similarly, the use of a PISR correction term in Eq. (6) covering only the time span between noon and acquisition time has no appreciable influence on the results of our statistical analyses considering the estimated standard errors of model coefficients. 
Table 5. Linear mixed models relating remotely-sensed and in-situ ground thermal variables to site characteristics at the logger sites and in the matched random sample. Non-significant coefficients in square brackets, FDR of all tests controlled at $\leq 10 \%$, no tests on the intercept.

\begin{tabular}{|c|c|c|c|c|c|c|c|}
\hline Response variable & Intercept & $E L E V_{3000} \times 100$ & $r P I S R_{p}{ }^{\text {a }}$ & $R G L$ & $D G L$ & $R D G L$ & COARSE ${ }^{\mathrm{b}}$ \\
\hline \multicolumn{8}{|c|}{ Remotely-sensed variables (matched sample) } \\
\hline$L S T_{\text {day }}$ & $21.32(0.32)$ & $-1.07(0.06)$ & $17.80(0.94)$ & $-1.51(0.24)$ & $-1.21(0.33)$ & & \\
\hline$L S T_{\text {night }}$ & $2.66(0.11)$ & $-0.90(0.02)$ & $3.87^{\mathrm{a}}(0.28)$ & $0.41(0.08)$ & {$[0.02](0.12)$} & & \\
\hline$L S T_{\mathrm{amp}}$ & $18.9(0.36)$ & $-0.23(0.07)$ & $15.85(1.10)$ & $-1.97(0.27)$ & $-0.97(0.41)$ & & \\
\hline$A T I$ & $0.229(0.006)$ & $0.003(0.001)$ & & $0.032(0.0004)$ & {$[0.008](0.006)$} & & \\
\hline \multicolumn{8}{|c|}{ Remotely-sensed variables (logger sites) } \\
\hline$L S T_{\text {day }}$ & $21.29(1.42)$ & $-1.25(0.24)$ & $14.45(3.32)$ & & & {$[-1.92](1.14)$} & {$[-1.25](1.07)$} \\
\hline$L S T_{\text {night }}$ & $3.53(0.39)$ & $-1.07(0.07)$ & {$[1.26]^{a}(0.88)$} & & & {$[0.33](0.27)$} & {$[-0.27](0.22)$} \\
\hline$L S T_{\mathrm{amp}}$ & $17.34(1.59)$ & {$[-0.16](0.27)$} & $12.29(3.70)$ & & & {$[-1.83](1.25)$} & {$[-0.70](1.14)$} \\
\hline$A T I$ & $0.228(0.038)$ & {$[0.002](0.006)$} & & & & {$[0.047](0.031)$} & {$[0.037](0.029)$} \\
\hline \multicolumn{8}{|c|}{ In-situ variables (logger sites) } \\
\hline$N S G T_{\text {day }}$ & $26.31(1.57)$ & $-1.92(0.26)$ & $13.00(3.69)$ & & & $3.66(1.30)$ & {$[-1.26](1.25)$} \\
\hline$N S G T_{\text {night }}$ & $9.08(0.68)$ & $-0.96(0.12)$ & [1.17] (1.59) & & & {$[0.70](0.58)$} & {$[-1.01](0.56)$} \\
\hline$N S G T_{\mathrm{amp}}$ & $17.18(1.78)$ & $-0.92(0.30)$ & $12.62(4.16)$ & & & {$[2.91](1.48)$} & {$[-0.53](1.43)$} \\
\hline$M A N S G T^{\mathrm{c}}$ & $7.96(0.37)$ & $-1.04(0.06)$ & {$[1.45](0.90)$} & & & {$[0.72](0.30)$} & $-0.92(0.28)$ \\
\hline
\end{tabular}

${ }^{\text {a }} r P I S R_{p}$ was used for all response variables except $L S T_{\text {night }} N S G T_{\text {night }}$ and MANSGT, for which $r P I S R$ was used.

${ }^{\mathrm{b}}$ In-situ observation at the logger site; not necessarily representative of entire ASTER grid cell.

${ }^{\mathrm{c}}$ Compare Apaloo et al. (submitted) for more detailed results relating MANSGT to site characteristics.

Table 6. AUROC values expressing the ability of ATI to discriminate between different ice-debris accumulations and other debris surfaces.

\begin{tabular}{llll}
\hline Data set & $R G L$ & $D G L$ & $R D G$ \\
Matched sample & 0.617 & 0.568 & 0.605 \\
Logger sample & & & 0.738 \\
\hline
\end{tabular}

\section{Discussion}

\subsection{Spatial patterns revealed by thermal imaging}

Remotely-sensed and in-situ observations of spatial patterns of daytime and nighttime surface temperatures in the high Andes agree reasonably well in terms of their correlation as well as statistically estimated topoclimatic influences. The utility of thermal imaging based on ASTER data may therefore not be limited to debris-covered glaciers with a shallow $(<40 \mathrm{~cm}$ ) debris cover (Mihalcea et al., 2008), but it also shows potential for analysing spatial patterns in periglacial environments in snow-free and especially dry conditions (Van De Kerchove et al., 2009; Bertoldi et al., 2010).

Nevertheless, in-situ point observations and spatially aggregated remote-sensing data provided contrasting results for the daytime temperature difference between ice-debris landforms and their surroundings, under otherwise equal site conditions. At this time we can only speculate about the causes of this disagreement, such as scale differences between ASTER data and in-situ measurements or a possible bias introduced by site selection and the installation of instrumentation in heterogeneous surface materials and complex local topography (e.g. dark desert varnish on more stable rock surfaces; different grain size distributions, Hardgrove et al., 2010). Interestingly, similar disagreements between point-scale and spatially aggregated results have been found elsewhere with much larger sample sizes (Gubler et al., 2011: effect size of coarse surfaces $+1.66^{\circ} \mathrm{C}$ at the intra-footprint scale and $-1.66^{\circ} \mathrm{C}$ at the inter-footprint scale). Other possible confounders may be related to differences in turbulent wind fluxes between the image acquisition period and the reference period, in spite of our observation that results obtained from in-situ temperature measurements were insensitive to the choice of a particular reference period.

The spatial patterns of LST are in good agreement with what would be expected in this type of environment. The estimated lapse rate of $\sim-1{ }^{\circ} \mathrm{C} / 100 \mathrm{~m}$ was close to the dry adiabatic lapse rate both at daytime and nighttime, which is consistent with the consistently dry ground and air conditions in this climate during the summer months, and contrasts with weaker lapse rates encountered in more humid mountains (Rolland, 2002; Gubler et al., 2011). Daytime NSGT lapse rates $<-1{ }^{\circ} \mathrm{C} / 100 \mathrm{~m}$ in at the logger sites might be related to a greater exposure of the highest "level" of the stepped Punta Negra valley (above $\sim 3500 \mathrm{~m}$ a.s.l.) to westerly air flows, leading to an enhanced cooling effect from the free atmosphere. By contrast, thermally-induced air flow that would weaken lapse rates appeared to be absent or weak. Temperature inversions also appeared to be absent, as evidenced by exploratory analyses showing linear altitudinal trends in daytime and especially nighttime LST and NSGT, supporting 
also that the use of linear lapse rates in this study was appropriate, in contrast to studies in other periglacial environments (Lewkowicz and Bonnaventure, 2011).

Topographically controlled exposure to solar radiation explained around $3{ }^{\circ} \mathrm{C}$ of temperature variation on a dry summer day (under a one-IQR difference in PISR), which reflects the strong effects of radiative heating in this generally cloudless environment during the summer months (Schrott, 1991).

\subsection{Thermophysical characteristics of ice-debris landforms}

This first, exploratory study that quantitatively examines differences in ATI between ice-debris landforms and their surroundings detected significant differences in ATI between intact rock glaciers and general debris surfaces under otherwise equal conditions. Although reduced $\mathrm{LST}_{\text {day }}$ is the main factor influencing ATI, the observed increase in nighttime LST that accompanies the stronger decrease in daytime LST on rock glaciers is consistent with an interpretation in terms of differing thermal inertia as a thermophysical material property (Watson, 1975).

However, ATI in this study and in cryospheric studies in general is a complex property (Fig. 4). A thermal gradient exists between ground surface and material at greater depth, in particular ground ice, which constitutes a thermal mismatch and a seasonal heat sink. Seasonal heat sinks at the lower boundary condition are not considered in the original ATI expression, which assumes only daily and not annual periodic heating. ATI in cryospheric conditions is therefore controlled by thermal inertia and the thickness of the surface layer (Bandfield and Feldman, 2008). Daytime (nighttime) latent heat absorption (release) at the top of ground ice and conductive cooling (warming) of the ground surface by this heat sink is small in the case of debris-layer thicknesses $>1 \mathrm{~m}$ (Mihalcea et al., 2008; Mattson et al., 1993; Nicholson and Benn, 2006), but a contribution to a daytime LST $_{\text {day }}$ reduction (nighttime increase) may still be possible. While direct observations of ground ice temperatures and heat fluxes are not available in this area, the low elevation of rock glaciers with respect to the regional ZIA of MAAT (Brenning, 2005b; Bodin et al., 2010) and borehole observations on such rock glaciers in other parts of the semiarid Andes (Monnier et al., 2011) suggest that ground ice in rock glaciers may likely be at the melting point. These effects are expected to be more pronounced on debris-covered glacier surfaces, which is consistent with the results of our post-hoc analysis, which accounts for a possible influence of anisotropic reflection.

Differences in thermal conductivity and heat capacity between an ice-free surface layer and a second, ice-rich layer may also influence heat transfer and NSGT at daytime in particular, resulting in a modified ATI. Such effects have been measured for groundwater tables at $1-3.5 \mathrm{~m}$ depth (Alkhaier et al., 2009) and may have contributed to ATI differences observed in this study. Further research of these phenomena is therefore warranted for a debris-ground ice stratification.

The presence of coarse blocky material in the surface layer of ice-debris landforms is another possible explanation for observed ATI and $\mathrm{LST}_{\text {day }}$ differences between ice-debris landforms and other debris surfaces. This influence was controlled for in the analysis of logger-site data; it is discussed separately in Sect. 5.3. However, coarse blocky layers may only partly explain the mentioned differences because coarse surface layers may also be present in other areas such as talus slopes. Additional causes for observed ATI and LST day differences may be related to confounding with several factors including rock type, weathering and (less likely here) soil moisture, each of which has complex relationships with the overall material density, heat capacity and conductivity.

\subsection{Thermophysical characteristics of coarse blocky layers}

Coarse blocky substrates, which are often present on icedebris landforms but also on talus slopes, have been described by several authors as presenting distinct thermal characteristics and thermophysical properties (Fig. 4). In particular, cold air circulation through the snow cover during winter has been presented as an explanation for undercooled coarse debris in marginal permafrost environments, and low thermal conductivity has been used to explain a strong thermal offset between ground surface and top of permafrost in coarse blocky material (Harris and Pedersen, 1998; Delaloye and Lambiel, 2005; Gruber and Hoelzle, 2008). While low thermal conductivities would reduce the thermal inertia of openwork boulder layers with poor thermal coupling between particles (Eq. (2)), well-coupled, matrix-supported blocky layers may exhibit the contrary effect. In these substrates, large boulders connecting the ground surface with greater depths offer a higher thermal conductivity and density and therefore increase thermal inertia relative to finer material or openwork boulders (Fig. 4; Bandfield, 2007; Bandfield and Feldman, 2008).

In our study, sites with coarse blocky surface layers were found to have (non-significantly) reduced daily NSGT and LST amplitudes and increased ATI, suggesting that in this particular area reduced thermal conductivities and/or densities may have been present in coarse blocky substrates. While the empirical evidence for this phenomenon is limited in this study, this shows that additional in-situ analyses of near-surface sediment structure are required in order to better interpret LST patterns. Spatial differences in turbulent heat flux may also constitute a possible uncontrolled confounder because turbulent heat flux is expected to be higher on coarser surfaces. 


$\begin{aligned} & \text { a) Effect of substrate type on thermal inertia and ATI } \\ & \text { Material }\end{aligned}$
$\begin{aligned} & \text { Matrix-supported } \\ & \text { blocky subtrate } \\ & \text { section } \\ & \text { density I }\end{aligned}$

b) Effect of thermal mismatch and heat sink on ATI

\begin{tabular}{|c|c|c|c|c|c|}
\hline Layering & $\begin{array}{l}\text { Latent } \\
\text { heat } \\
\text { absorption }\end{array}$ & $\begin{array}{l}\text { Heat } \\
\text { conduction }\end{array}$ & $\begin{array}{l}\text { Thermal } \\
\text { gradient }\end{array}$ & $\begin{array}{l}\text { Daytime } \\
\text { LST/NSGT } \\
\text { reduction }\end{array}$ & ATI \\
\hline $\begin{array}{l}\text { Thin debris layer; } \\
\text { temperate ice }\end{array}$ & Increased & Increased & Strong & Strong & High \\
\hline $\begin{array}{l}\text { Thick debris layer; } \\
\text { ice-rich } \\
\text { permafrost near } \\
\text { melting point }\end{array}$ & Reduced & Reduced & Moderate & Weak? & Medium \\
\hline No ground ice & Minimal & Minimal & Weak & None & Low \\
\hline
\end{tabular}

Fig. 4. Effects of substrate type, thermal mismatch and presence of a heat sink on thermophysical properties, thermal conditions and ATI under dry, snow-free conditions in summer: a schematic overview. ATI is subject to the combined effects of thermal inertia as a thermophysical property and seasonal as well as diurnal heat transfer processes between the ground surface and greater depths.

\subsection{Utility of ATI for characterizing ice-debris landforms}

Compared to the direct use of LST to delineate ice-debris landforms (Taschner and Ranzi, 2002), ATI mapping practically eliminates the need to account for the strong altitudinal trend present in LST data. Our results show the general feasibility of ATI mapping in mountain terrain, and demonstrate the potentials of this approach in periglacial and glacial environments. However, while thermal inertia is usually interpreted based on the assumption of a homogeneous semi-infinite half space, a more complex situation is often found in these environments due to the presence of ground ice at variable depths and possible vertical material sorting (Fig. 4; Bandfield, 2007; Bandfield and Feldman, 2008). Physically-based modeling of typical layering features in combination with geophysical investigations would provide further valuable insight into how these structures are reflected in ATI maps.

The strong spatial variation in daily maximum surface temperatures further poses a challenge as it is often related to small topographic features that are smaller than the resolution of ASTER thermal imagery or widely available DEMs. A solar-corrected representation of ATI was therefore used in this study (Eq. (3)), which helped to reduce confounding with topographic effects on daytime LST in complex terrain. Methods using the drop in surface temperature between sunset and sunrise instead of the daily temperature amplitude (Verhoef, 2004) may also be of particular interest in mountain areas because of their reduced dependence on local topography.

While previous studies emphasized the potential utility of ATI for mapping ice-debris landforms on Earth (southeastern Alaska) and potentially on Mars (Piatek, 2009), the present 
study is the first to produce quantitative assessment of the discrimination that can be achieved with this method. In our essentially vegetation-free study area, ATI proved to be of only very limited utility for mapping rock glaciers and debris-covered glaciers. The (visually) more promising results shown by Piatek (2009) can likely be attributed to the influence of vegetation, a darker upper soil horizon or moist soils on ATI in the area chosen by these authors as a terrestrial analog of Mars. Our findings are more likely transferable to dry mountain areas on Earth, or to Mars. Given the weak (but potentially useful) discrimination of ice-debris landforms provided by ATI, we suggest combining this variable with terrain attributes and other remotely-sensed variables (Brenning, 2009; Brenning and Azócar, 2010).

\section{Conclusions}

Remotely-sensed LST and ATI provide insights into land surface processes and thermophysical surface characteristics that complement local in-situ observations. In the present study, ASTER-derived daytime and nighttime LST showed similar spatial patterns as in-situ observations of NSGT, although the comparison of measurements obtained at different spatial scales creates several challenges. ASTER-derived ATI of rock glaciers and debris-covered glaciers differed from the inertia of other vegetation-free debris surfaces in the study area, and ice-debris landforms exhibited reduced daytime LST under otherwise equal conditions.

Acknowledgements. This research was funded through an IDRC Latin America and the Caribbean Research Exchange Grant and a NSERC Discovery Grant awarded to A. Brenning. The authors would like to thank J. B. Apaloo for processing in-situ ground thermal data, X. Bodin and several students for assistance in the field, and Aguas Andinas and the Dirección General de Aguas for providing weather data and logistical support. We further thank the referees for their thoughtful comments, which helped to improve this paper.

Edited by: A. Nolin

\section{References}

Alkhaier, F., Schotting, R. J., and Su, Z.: A qualitative description of shallow groundwater effect on surface temperature of bare soil, Hydrol. Earth Syst. Sci., 13, 1749-1756, 2009,

http://www.hydrol-earth-syst-sci.net/13/1749/2009/.

Apaloo, J., Brenning, A., and Bodin, X.: Interactions between snow cover, ground surface temperature and topography (Andes of Santiago, Chile, 33.5 ${ }^{\circ}$ S), Permafrost Periglac., submitted, 2012.

ASTER Science Office: ASTER SWIR Data Status Report, 13 March 2009, available online at: http://www.science.aster. ersdac.or.jp/en/about_aster/swir_en.pdf, 2009.

Bandfield, J. L.: High-resolution subsurface water-ice distributions on Mars, Nature, 447, 64-67, doi:10.1038/nature05781, 2007.
Bandfield, J. L. and Feldman, W. C.: Martian high latitude permafrost depth and surface cover thermal inertia distributions, J. Geophys. R., 113, E08001, doi:10.1029/2007JE003007, 2008.

Benjamini, Y. and Hochberg, Y.: Controlling the false discovery rate: A practical and powerful approach to multiple testing, J. Roy. Stat. Soc. B, 57, 289-300, 1995.

Berthling, I.: Beyond confusion: rock glaciers as cryoconditioned landforms, Geomorphology, 131, 98-106, doi:10.1016/j.geomorph.2011.05.002, 2011.

Bertoldi, G., Notarnicola, C., Leitinger, G., Endrizzi, S., Zebisch, M., Della Chiesa, S., and Tappeiner, U.: Topographical and ecohydrological controls on land surface temperature in an alpine catchment, Ecohydrology, 3, 189-204, 2010

Bodin, X., Rojas, F., and Brenning, A.: Status and evolution of the cryosphere in the Andes of Santiago (Chile, $33.5^{\circ} \mathrm{S}$.), Geomorphology, 118, 453-464. doi:10.1016/j.geomorph.2010.02.016, 2010a.

Bodin, X., Azócar, G. F., and Brenning, A.: Recent (2004-2010) variations of surface displacements in an Andean permafrostglacier environment (Chile, $33^{\circ}$ S.), in: Abstracts, Third European Conference on Permafrost, 13-17 June 2010, Svalbard, Norway, 46, 2010b.

Bolch, T., Buchroithner, M. F., Kunert, A., and Kamp, U.: Automated delineation of debris-covered glaciers based on ASTER data, in: GeoInformation in Europe, edited by: Gomarasca, M. A., Proceedings, 27th EARSeL Symposium, 4-7 June 2007, Bozen, Italy, Millpress, Netherlands, 403-410, 2008.

Brenning, A.: Climatic and geomorphological controls of rock glaciers in the Andes of Central Chile: Combining statistical modelling and field mapping, Ph.D., Humboldt-Universität zu Berlin, Berlin, urn:nbn:de:kobv:11-10049648, 2005a.

Brenning, A.: Geomorphological, hydrological and climatic significance of rock glaciers in the Andes of Central Chile (33-35 $\mathrm{S})$, Permafrost Periglac., 16, 231-240, doi:10.1002/ppp.528, 2005b.

Brenning, A.: Statistical geocomputing combining R and SAGA: The example of landslide susceptibility analysis with generalized additive models, in: SAGA - Seconds out, edited by: Böhner, J., Blaschke, T., and Montanarella, L., Hamburger Beiträge zur Physischen Geographie und Landschaftsökologie, 19, 23-32, 2008.

Brenning, A.: Benchmarking classifiers to optimally integrate terrain analysis and multispectral remote sensing in automatic rock glacier detection, Remote Sens. Environ., 113, 239-247, doi:10.1016/j.rse.2008.09.005, 2009.

Brenning, A. and Azócar, G. F.: Statistical analysis of topographic and climatic controls and multispectral signatures of rock glaciers in the dry Andes, Chile $\left(27^{\circ}-33^{\circ} \mathrm{S}\right)$, Permafrost and Periglacial Processes, 21, 54-66, doi:10.1002/ppp.670, 2010.

Carrasco, J. F., Casassa, G., and Quintana, J.: Changes of the $0{ }^{\circ} \mathrm{C}$ isotherm and the equilibrium line altitude in central Chile during the last quarter of the 20th century, Hydrologic. Sci. J., 50, 933948, 2005.

Chen, Z., Li, S., Ren, J., Pan, G., Zhang, M., Wang, L., Xiao, S., and Jiang, D.: Monitoring and management of agriculture with remote sensing, in: Advances in Land Remote Sensing, edited by: Liang, S., Springer, Dordrecht, 397-421, 2008.

Conrad, O.: SAGA - Program structure and current state of implementation, in: SAGA - Analysis and Modelling Applications, edited by: Böhner, J., McCloy, K. R., and Strobl, J., Göttinger Geographische Abhandlungen, 115, 39-52, 2006. 
Delaloye, R. and Lambiel, C.: Evidence of winter ascending air circulation throughout talus slopes and rock glaciers situated in the lower belt of alpine discontinuous permafrost (Swiss Alps), Norsk Geogr. Tidsskr., 59, 194-203, doi:10.1080/00291950510020673, 2005.

Farías, M., Charrier, R., Carretier, S., Martinod, J., Fock, A., Campbell, A., Cáceres, J., and Comte, D.: Late Miocene high and rapid surface uplift and its erosional response in the Andes of central Chile $\left(33^{\circ}-35^{\circ} \mathrm{S}\right)$, Tectonics, 27, TC1005, doi:10.1029/2006TC002046, 2008

Fock, A., Charrier, R., Farías, R., Maksaev, V., Fanning, M., and Álvarez, P.: Exhumation and uplift of the western Main Cordillera between $33^{\circ}$ and $34^{\circ} \mathrm{S}$, in: Extended Abstracts, 6th International Symposium on Andean Geodynamics, ISAG 2005, Barcelona 273-276, 2005.

Geiger, R., Aron, R. H., and Todhunter, P.: The climate near the ground, sixth edition, Rowman and Littlefield Publ., Lanham, MD, USA, 2003.

Gillespie, A.: Lithologic mapping of silicate rocks using TIMS, in: Proceedings of the TIMS data user's workshop, JPL Publication 86-38, Pasadena CA, 29-44, 1986.

Gruber, S. and Hoelzle, M.: The cooling effect of coarse blocks revisited: a modeling study of a purely conductive mechanism, in: 9th International Conference on Permafrost, Fairbanks, Alaska, 30 June-3 July 2008, 1, 557-561, 2008.

Gubler, S., Fiddes, J., Keller, M., and Gruber, S.: Scaledependent measurement and analysis of ground surface temperature variability in alpine terrain, The Cryosphere, 5, 431-443, doi:10.5194/tc-5-431-2011, 2011.

Haeberli, W.: Modern research perspectives relating to permafrost creep and rock glaciers: a discussion, Permafrost Periglac., 11, 290-293, 2001.

Haeberli, W., Hallet, B., Arenson, L., Elconin, R., Humlum, O., Kääb, A., Kaufmann, V., Ladanyi, B., Matsuoka, N., Springman, S., and Vonder Mühll, D.: Permafrost creep and rock glacier dynamics, Permafrost Periglac., 17, 189-214, doi:10.1002/ppp.561, 2006.

Hafner, J. and Kidder, S. Q.: Urban heat island modeling in conjunction with satellite-derived surface/soil parameters, J. Appl. Meteorol., 38, 448-465, 1999.

Hardgrove, C., Moersch, J., and Whisner, S.: Thermal imaging of sedimentary features on alluvial fans, Planet. Space Sci., 58, 482-508, doi:10.1016/j.pss.2009.08.012, 2010.

Harris, S. A. and Pedersen, D. E.: Thermal regimes beneath coarse blocky materials, Permafrost Periglac., 9, 107120, doi:10.1002/(SICI)1099-1530(199804/06)9:2<107::AIDPPP277>3.0.CO;2-G, 1998.

Hartz, D. A., Prashad, L., Hedquist, B. C., Golden, J., and Brazel, A. J.: Linking satellite images and hand-held infrared thermography to observed neighborhood climate conditions, Remote Sens. Environ., 104, 190-200, 2006.

Hayakawa, Y., Oguchi, T., and Lin, Z.: Comparison of new and existing global digital elevation models: ASTER G-DEM and SRTM-3, Geophys. Res. Lett., 35, L17404, doi:10.1029/2008GL035036, 2008.

Janke, J. R.: Rock glacier mapping: a method utilizing enhanced TM data and GIS modeling techniques, Geocarto Int., 16, 5-15, 2001.
Kargel, J. S., Abrams, M. J., Bishop, M. P., Bush, A., Hamilton, G., Jiskoot, H., Kääb, A., Kieffer, H. H., Lee, E. M., Paul, F., Rau, F., Raup, B., Shroder, J. F., Soltesz, D., Stainforth, D., Stearns, L., and Wessels, R.: Multispectral imaging contributions to global land ice measurements from space, Remote Sens. Environ., 99, 187-219, doi:10.1016/j.rse.2005.07.004, 2005.

Knap, W. H., Reijmer, C. H., and Oerlemans, J.: Narrowband to broadband conversion of Landsat TM glacier albedos, Int. J. Remote Sens., 20, 2091-2110, 1999.

Lewkowicz, A. G. and Bonnaventure, P. P.: Equivalent elevation: a new method to incorporate variable surface lapse rates into mountain permafrost modelling, Permafrost Periglac., 22, 153162, 2011.

Li, X., Liu, A., Zhang, S., Wang, Z., Sun, W., and Wang, P.: A study on thermal inertia approach for agriculture drought monitoring in Shaanxi Province, China by using NOAA/AVHRR data, in: Proceedings, IEEE International Geoscience and Remote Sensing Symposium, 6, 4031-4033, doi:10.1109/IGARSS.2004.1370014, 20-24 September 2004, Anchorage, AK, 2004.

Liang, S.: Narrowband to broadband conversions of land surface albedo I Algorithms, Remote Sens. Environ., 76, 213-238, 2000

Lillesand, T. M., Kiefer, R. W., and Chipman, J. W.: Remote sensing and image interpretation, fifth edition, John Wiley \& Sons, New York, 2004.

Mattson, L. E., Gardner, J. S., and Young, G. J.: Ablation on debris covered glaciers: an example from the Rakhiot Glacier, Punjab, Himalaya, in: IAHS Publ. 218, Snow and Glacier Hydrology Symposium, Kathmandu, Nepal, 1992, 289-296, 16-21 November 1992, IAHS Press, Institute of Hydrology, Wallingford, Oxfordshire, UK, 1993.

Mihalcea, C., Brock, B. W., Diolaiuti, G., D’Agata, C., Citterio, M., Kirkbride, M. P., Cutler, M. E. J., and Smiraglia, C.: Using ASTER satellite and ground-based surface temperature measurements to derive supraglacial debris cover and thickness patterns on Miage Glacier (Mont Blanc Massif, Italy), Cold Regions Science and Technology, 52, 341-354, doi:10.1016/j.coldregions.2007.03.004, 2008.

Monnier, S., Kinnard, C., Saez, R., Garrido, R., Camerlynck, C., and Rejiba, F.: The internal structure and the cryologic importance of the rock glaciers of the Los Pelambres mine (Upper Choapa Valley, semi-arid Andes of Chile), Geophys. Res. Abstr., 13, EGU2011-4165, 2011.

Nasipuri, P., Majumdar, T. J., and Mitra, D. S.: Study of high-resolution thermal inertia over western India oil fields using ASTER data, Astronaut. Acta, 58, 270-278, doi:10.1016/j.actaastro.2005.11.002, 2006.

Nichol, J. E.: High-resolution surface temperature patterns related to urban morphology in a tropical city: a satellite-based study, J. Appl. Meteorol., 35, 135-146, 1996.

Nicholson, L. and Benn, D.: Calculating ice melt beneath a debris layer using meteorological data, J. Glaciol., 52, 463-470, 2006.

Paul, F., Huggel, C., and Kääb, A.: Combining satellite multispectral image data and a digital elevation model for mapping of debris-covered glaciers, Remote Sens. Environ., 89, 510-518, doi:10.1016/j.rse.2003.11.007, 2004.

Peña, M. A.: Examination of the land surface temperature response for Santiago, Chile, Photogramm. Eng. Rem. S., 75, 1191-1200, 2009. 
Piatek, J. L.: Thermophysical properties of terrestrial rock and debris-covered glaciers as analogs for Martian lobate debris aprons, 40th Lunar and Planetary Science Conference, Lunar and Planetary Science XL, held 23-27 March 2009 in The Woodlands, Texas, 2127, 2009.

Piatek, J. L., Hardgrove, C., and Moersch, J. E.: Potential rock glaciers on Mars: comparison with terrestrial analogs, in: Seventh International Conference on Mars, held 9-13 July 2007 in Pasadena, California, LPI Contribution No. 1353, 3353, 2007.

Pinheiro, J., Bates, D., DebRoy, S., Sarkar, D., and the R Development Core Team: linear and nonlinear mixed effects models, $\mathrm{R}$ package version 3.1-96, 2009.

Price, J. C.: On the analysis of thermal infrared imagery: the limited utility of apparent thermal inertia, Remote Sens. Environ., 18, 59-73, 1985.

R Development Core Team: R: a language and environment for statistical computing, R Foundation for Statistical Computing, Vienna, Austria, ISBN 3-900051-07-0, available at: http://www. R-project.org, 2010.

Realmuto, V. J.: Separating the effects of temperature and emissivity: emissivity spectrum normalization, in: Proceedings of the 2nd TIMS Workshop, JPL Publication 90-55, Pasadena CA, 2327, 1990.

Reid, T. D. and Brock, B. W.: An energy-balance model for debriscovered glaciers including heat conduction through the debris layer J. Glaciol., 56, 903-916, 2010.

Rolland, C.: Spatial and seasonal variations of air temperature lapse rates in alpine regions, J. Climate, 16, 1032-1046, 2002.

Schrott, L.: Global solar radiation, soil temperature and permafrost in the Central Andes, Argentina: a progress report, Permafrost Periglac., 2, 59-66, 1991.

Shukla, A., Arora, M. K., and Gupta, R. P.: Synergistic approach for mapping debris-covered glaciers using optical-thermal remote sensing data with inputs from geomorphometric parameters, Remote Sens. Environ., 114, 1378-1387, 2010.
Sing, T., Sander, O., Beerenwinkel, N., and Lengauer, T.: ROCR: Visualizing the performance of scoring classifiers, $\mathrm{R}$ package version 1.0-4, available at: http://CRAN.R-project.org/package= ROCR, The R Foundation for Statistical Computing, Vienna, 2009.

Taschner, S. and Ranzi, R.: Comparing the opportunities of Landsat-TM and Aster data for monitoring a debris covered glacier in the Italian Alps within the GLIMS project, IEEE Geoscience and Remote Sensing Symposium, 2, 1044-1046, 2002.

Trombotto, D. and Borzotta, E.: Indicators of present global warming through changes in active layer-thickness, estimation of thermal diffusivity and geomorphological observations in the Morenas Coloradas rockglacier, Central Andes of Mendoza, Argentina, Cold Reg. Sci. Technol., 55, 321-330, 2009.

Van De Kerchove, R., Goossens, R., De Wulf, A., Bourgeois, J., and Gheyle, W.: Thermal remote sensing imagery in permafrost studies, in: Proceedings of the 28th Symposium of the European Association of Remote Sensing Laboratories, 313-320, doi:10.3233/978-1-58603-986-8-313, 2008.

Van doninck, J., Peters, J., De Baets, B., De Clercq, E. M., Ducheyne, E., and Verhoest, N. E. C.: The potential of multitemporal Aqua and Terra MODIS apparent thermal inertia as a soil moisture indicator, Int. J. Appl. Earth Obs Geoinf., 13, 934 941, doi:10.1016/j.jag.2011.07.003, 2011.

Verhoef, A.: Remote estimation of thermal inertia and soil heat flux for bare soil, Agr. Forest Meteorol., 123, 221-236, 2004.

Wan, Z.: A physics-based algorithm for retrieving land-surface emissivity and temperature from EOS/MODIS data, IEEE T. Geosci. Remote, 35, 980-996, 1997.

Watson, K.: Geologic applications of thermal infrared images, Proceedings of the IEEE, 63, 128-137, 1975.

Weng, Q. and Quattrochi, D. A.: Thermal remote sensing of urban areas: An introduction to the special issue, Remote Sens. Environ., 104, 119-122, 2006. 